\title{
MERCHANDISE TRADE DEFICIT AND IMPORT SUBSTITUTION FOR NEPAL
}

\author{
Kshitiz poudel \\ Collage of Economic and Management, \\ Nanjing University of Aeronautics and Astronautics, China \\ DOI: 10.46609/IJSSER.2020.v05i07.009 URL: https://doi.org/10.46609/IJSSER.2020.v05i07.009
}

\begin{abstract}
This study investigates Nepal disaggregate import function for three categories, FOOD, FUEL (food and live animal, mineral fuel and lubricant) and MACHINERY capital goods (machinery and transport equipment) from 1974 to 2018. In this work, we will Use the cointegration analysis and Vector auto regression model (VAR). The main aim of this paper is to find out whether it is possible to substitute these imports (food and live animal, mineral fuel and lubricant, machinery and transport equipment) with domestic production. Using real exchange rate and real gross domestic product as explanatory variables. The empirical result show that change in GDP cause major change to machinery and food imports while the real exchange rate is statistically insignificant in determining imports of food, machinery and fuel, implying that exchange rate policies would be ineffective in regulating imports in Nepal. Therefore, Nepal has to be careful when applying certain policies during implementation of development plans. That is to say, policies have to favor those industries that produce commodities that can in turn compete locally with imports.
\end{abstract}

Keywords: Import Substitution, Nepal, GDP, Exchange Rate, Food, Machinery, Fuel

\section{INTRODUCTION}

Merchandise Trade is Import and Export of goods. Nepalese foreign trade is increased considerably, but the tendency of the Nepalese trade balance is a permanent deficit due to imports exceeding exports. Nepal is fully dependent on foreign loans and aids, which are further underutilized rather than increasing the Nepalese economy. For the favorable balance of trade, export has to increase, and it has to exceed imports. But the land-locked country, a vicious circle of poverty, stagnation, lack of export credit, etc. are the main cause for stagnant export and 
increasing imports. Hence there is a poor economy and permanent increasing deficit in the trade balance.

Nepal is an agriculture country and agricultural product exporting country, and one-third of GDP is contributed by agriculture. The industrial products are unable to meet the domestic demand, and industrialization is still in the infant stage, and the phase is creeping. The exported goods are unable to compete with international markets because of low-quality products. Therefore, Nepalese foreign trade is in bad condition. There is a problem of trade diversification in terms of both commodities wise and destination wise. That is because we are mostly offering the same product to the same destination. But import is more diversified the comparison to export when the import trade exceeds export there is no question of surplus. The balance of trade position of Nepal has to face the problem of trade deficit. The government policy of trade diversification will be intended to import diversification to promote export, and there is a huge need for export credit. But Nepalese trade agencies and organization are not getting sufficient financial sector. However, opening a few commercial banks may provide financial support to promote export.

Figure 1: Nepal -Trade Balance, percentage of GDP

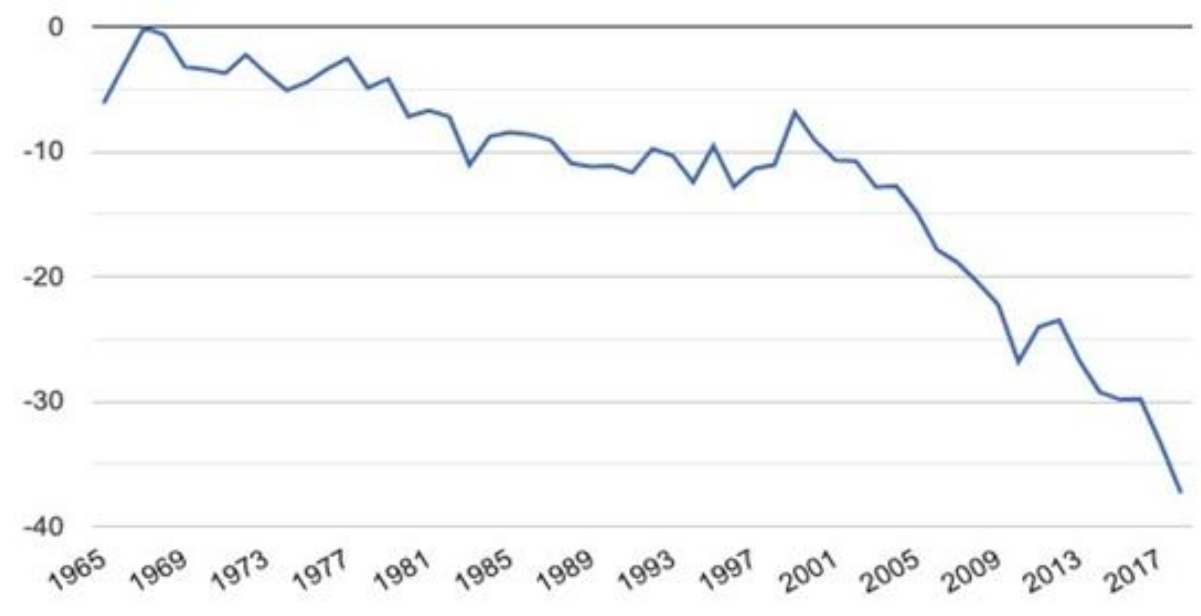

(Source: TheGlobalEconomy.com, The world bank)

In the above figure, we can explain that Trade balance (export -Import) percentage of GDP is negative from 1965 to 2017. Negative doesn't always mean Trade deficit have negative impact on economy but in case of Nepal average value during 1965-2017 is -12\% with minimum of $37 \%$ in 2018 and maximum of 0.08 percent in 1967. World average in 2018 was -4.70 . From above figure we can argue that Merchandise Trade deficit have negative impact in GDP and it's increasing. 


\section{International Journal of Social Science and Economic Research}

ISSN: $2455-8834$

Volume: 05, Issue: 07 "July 2020"

The major concern for Nepal to benefit from trade is its slow growth in export compare to import. The average export growth rate is $4.2 \%$ in the last ten years. But it was $18.2 \%$ percent in imports. India is the export destination of Nepalese goods and services with absorbing 66 percent of Nepal's export. The major export of Nepal to India are textiles, zinc sheet polyester yarn, juice, and jute product, which represented 43 percent of the total export to India. Being the northern neighbor and also the second-largest economy, china only absorbed $3 \%$ of Nepal's total export on average in the last five years. Major commodities exported to china are tanned skin, handicraft, woolen carpet, and noodles. Exports to other countries expect India and china also include similar products such as woolen carpet, ready-made garments, pashmina, which is almost half of the total export.

Table 1: Commodity Trade by SITC Group 2015/16

\begin{tabular}{|c|c|c|c|c|c|}
\hline \multirow{2}{*}{ S.N. } & \multirow{2}{*}{ SITC Group } & \multicolumn{2}{|c|}{$\begin{array}{c}\text { Export } \\
\text { s }\end{array}$} & \multicolumn{2}{|c|}{$\begin{array}{c}\text { Import } \\
\mathrm{s}\end{array}$} \\
\hline & & $\begin{array}{l}\text { Rs. in } \\
\text { Million }\end{array}$ & $\begin{array}{c}\text { In } \\
\text { Percentage }\end{array}$ & $\begin{array}{l}\text { Rs. in } \\
\text { Million }\end{array}$ & $\begin{array}{c}\text { In } \\
\text { percentage }\end{array}$ \\
\hline 1 & Food and live animals & 16421 & $23.42 \%$ & 109756 & $14.19 \%$ \\
\hline 2 & Tobacco and beverage & 478 & $0.68 \%$ & 6413 & $0.83 \%$ \\
\hline 3 & Crude materials and inedibles & 2218 & $3.16 \%$ & 33392 & $4.32 \%$ \\
\hline 4 & $\begin{array}{l}\text { Minerals, Fuels, and } \\
\text { lubricants }\end{array}$ & 1 & $0.00 \%$ & 84088 & $10.87 \%$ \\
\hline 5 & $\begin{array}{l}\text { Animals and vegetable oils } \\
\text { and fats }\end{array}$ & 107 & $0.15 \%$ & 21153 & $2.73 \%$ \\
\hline 6 & Chemical and drugs & 4618 & $6.59 \%$ & 103962 & $13.44 \%$ \\
\hline 7 & Classified by materials & 32666 & $46.59 \%$ & 163132 & $21.09 \%$ \\
\hline 8 & $\begin{array}{l}\text { Machinery and transport } \\
\text { equipments }\end{array}$ & 400 & $0.57 \%$ & 189764 & $24.53 \%$ \\
\hline 9 & Misc. manafactured articles & 13205 & $18.83 \%$ & 45864 & $5.93 \%$ \\
\hline 10 & Not classified & 3 & $0.00 \%$ & 16074 & $2.08 \%$ \\
\hline & Total & 70117 & $100.00 \%$ & 773598 & $100.00 \%$ \\
\hline
\end{tabular}

(source: Economic Survey, 2016/17)

Imports and exports can explain the composition of Nepal's foreign trade:

Exports: The major exportable goods of Nepal are woolen goods, carpets (hand-knotted woolen), paper products, readymade garments, handicrafts, ornaments, pashmina, etc. These goods are exported to India and other countries. 


\section{International Journal of Social Science and Economic Research}

ISSN: $2455-8834$

Volume: 05, Issue: 07 "July 2020"

Import: The major goods imported in Nepal are various finished goods, semi-finished goods, raw materials of industry, machinery, equipment, chemical fertilizers, petroleum products, gold, electrical goods, readymade garments, etc. From the economy survey 2016/17, it is clear that the value of machinery and transport equipment had occupied first position (24.53\%); similarly, the second position was occupied by classified by materials $(24.53 \%)$ and the third "food and live animals" has occupied (14.19\%).

In 2015 Nepal faced an unofficial blockade from India at that time fuel crisis was at its pick. Food and fuel were highly affected product at that time. Nepal is a developing country, so the import of machinery and transport equipment is high. So, we decide to take three categories for our research. India imposed trade embargoes in 1969, 1989 and 2015. In all three occasions, the unilateral economic dependency was exploited to fulfil India's political interest in Nepal. Especially whenever Nepal has attempted to conduct policies that represent Nepal's exercise of sovereignty such as removing Indian military check posts from within Nepali territories, promulgation of its constitution, international recognition as a "Zone of Peace", opening up trade relations with China and so on. These embargoes were lifted after most of India's interests were accommodated by Nepal, at times as in 1989 after change in regime. The 2015 embargo was different. The embargo ended after heavy domestic criticism and India's own realization that the policy was counterproductive.

International trade has especially become a significant factor in the economic growth of Nepal. The substitution of foreign imports with domestic production has become the key component of the economic diversification drive. Import substitution and export-oriented strategies can promote the country' s economic growth through industrialization. Many authors (Rijal.koshal 2000, Naryan and Narayan 2005, Hibbert, Thaver 2012) argue that the effectiveness of international trade policy depends on the elasticity of import and export elasticity. In other words, knowledge of import and export elasticity are vita for an economy that is trying to diversify since they help in formulating appropriate international trade policy. For example, if policymakers want to save on foreign exchange use by reducing imports through increasing import prices, it will be ineffective if the imports demand function is price inelastic. Instead, demand for foreign exchange would increase, rather than decrease, with the increase in price, so it's a need to estimate the import demand function.

After 1980 Nepal adopted a liberalization policy and opened up a border for international trade and move forward inward-looking strategy to outward-looking strategy. After the implementation of open economic policy, Nepal has entered in several bilateral, regional, and multilateral trade agreements. Nepal is a member of Two Major Trade group, both form 2004 they are: South Asian Free Trade Area (SAFTA) and (BIMSTEC) Bay of Bengal Initiative for 


\section{International Journal of Social Science and Economic Research}

ISSN: $2455-8834$

Volume: 05, Issue: 07 "July 2020"

multi-sectoral trade and economic and Since 2004 Nepal becomes the first least developed country to become a member of the WTO (World Trade Organization) in 2004. It indicates that Nepal moves towards open economic policy and commitment towards international trade and global competition. Economic growth performance of Nepal. As mention suggested by (Khatiwada and Sharma,2002), the import substitution industries and export-oriented industries may help Nepal to come out of the continuous unbalance trade.

This study examines the import demand function of consumer goods FOOD, FUEL (food and live animal, mineral fuel and lubricant) and capital goods MACHINERY (machinery and transport equipment) in Nepal; the objective is to determine which goods would be better candidates for import substitution, whether consumer goods such as food and oil, or producer goods such as machinery. Since Nepal import most of the commodities from India, the trading relationship between these countries is important to analyze. Food and live animals, mineral fuel, and lubricant are chosen over other commodities to be possible candidates for import substitution since they are produced by light industries, and also, they use less sophisticated technology as compared to heavy industries. These commodities do not require very high economies of scale in their production. Also, there are light food factories and hydroelectricity industries which are developed in Nepal, which can substitute the import of these commodities. So, it is important to investigate the extent to which the import of these commodities can be substituted with domestic production. For comparison, another commodity that can be investigated is machinery to see how it responds to the same determinants as for consumer goods, which are Food and live animals, mineral fuel.

In theory, import substitution can be determined by tariffs: a rise in tariffs of selected importcompeting sectors would protect the domestic sector, thus causing it to expand. This is through tariffs causing imports to become more expensive. However, another way would be through exchange rate changes. A depreciation of the Nepali rupee also leads to an increase in the price of imports, and therefore Nepal would import less. In the absence of an independent Tariff policy as an instrument of Trade policy (because of Nepal's membership in the various trade group), the exchange rate is the next best instrument that can be used to influence domestic prices of importable. It is, therefore, important to estimate import elasticities of selected commodities in relation to some variables that affect imports, in particular, the real exchange rate, to see which commodity is most responsive to a real exchange rate depreciation, and therefore which commodity is a good candidate for import substitution.

In this research, we estimate Nepal import demand function of the consumer versus capital goods. Specifically, the study aims to show how imports of the selected commodities of (1) Food, (2) Machinery, (3) Fuel respond to changes in relative price and income and base on the 


\section{International Journal of Social Science and Economic Research}

ISSN: $2455-8834$

Volume: 05, Issue: 07 "July 2020"

elasticities, to determine which commodities would be better candidates of import substitution.

\section{LITERATURE REVIEW}

The policy of import substitution is not new to the world community: a number of countries from Latin America to East Asia and Europe have circumvented several stages of its implementation. During the 1950s, 1960s, and 1970s, most developing countries attempted to industrialize through import substitution, rather than continuing to specialize in the production of primary commodities such as food, raw materials, and minerals for export. The positive result achieved form import substitution policy were the growth of employment, and the reduction of unemployment, complete utilization of national resources, the stimulation of the scientific and technological progress, improvement of living standard and economic sovereignty. Import substitution industrialization was seen to be important as it saved on foreign exchange hastened technological progress and was a source of creation of employment. Import substitution also helps to reduce foreign dependency through local production. Every country in the world has practice import substitution directly or indirectly in its developing state. Import substitution is a trade and economic policy that is used to replacing foreign imports with domestic production.

The change in the geopolitical situation and the imposition of the economic sanctions against Russian commodity producers showed the high import dependence. The modern, largely forced trend of import substitution in Russia is aimed at the maintenance of the food and national security while increasing the competitiveness of the economy (Kuzmin, 2015)

The countries of Latin America focused only on the domestic market without a combination of import substitution policy with the policy for promotion of the goods to the foreign market. The positive effect of the imposed import restrictions took place, but was very short-term. The annual growth of gross domestic product (hereinafter, GDP) amounted to 5.5\% in the period from 1950 to 1980 , the GDP growth per capita averaged to $2.7 \%$, and the increase in the quality of workers' skills and living standards was noted (Molchanova, 2015). However, the lack of competition and the introduction of import substitution policies in all areas of production resulted in the inefficient implementation of the industrial policy and, accordingly, the price increase. The inflation during the period of the import substitution program was very high and was measured in the 1980s in triplicate figures. The creation of new plants could not be compensated due to the uncompetitiveness of the products manufactured. This led to a decrease in the competitiveness of the national production.

(2002 Douglas) study tariff growth correlation of the late $19^{\text {th }}$ century in this study they found that rapid growth in Argentina and Canada, two high-tariff, high-growth outliers was based on an export orientation in staple products. Not industrialization based on import substitution. 


\section{International Journal of Social Science and Economic Research}

ISSN: $2455-8834$

Volume: 05, Issue: 07 "July 2020"

Fundamentally, like any demand function, and import demand function has income and relative price as the main determinants. Several studies, such as Magee (1975) and Goldstein (1985), have been undertaken to examine theoretical expectations of relative price and income variables. In most of all, studies on the import demand function, the relative price variable has been reported to have a negative sign while the income variable has a positive sign, as expected from economic theory. This means that import demand or volume of imports responds negatively to price and positively to income or the economic activity, which means that as an economy grows, it is expected to increase its demand for imports, although this dependence on imports may decline after Sometimes, as import substitution industrialization takes place.

Theoretically, economic activity is assumed to cause consumption to increase. In almost all studies on import demand, a positive relationship between import demand and income is reported. Nevertheless, the sign of the income coefficient is not necessarily positive since, for some importable such as inferior goods, it could be negative. Also, a negative income elasticity for the import of goods can occur if an increase in domestic income is due to an increase in import substitutes (Bahmani Oskooee and Niroomand 1998).

Several empirical studies have been undertaken to analyze the behavior of the import demand function. These studies included: Dutta and Ahemd (2004) for India, Rijal, Koshal(2000) for Nepal. The import function of these various countries has been vigorously analyzed using Johansen and Juselius (1990) cointegration test. The imports were found to be responsive to changes in income and relative import prices in the long run. The imports were found to be inelastic with respect to their own prices but elastic for real income.

Some studies (Seleka 2007, Aker 2008, Knwuka and Zoral 2009) have identified factors such as import controls, the openness of the economy, foreign direct investment (FDI) and fixed capital investment as influencing the import demand for a number of developing countries. Onwuka and Zoral (2009) argued that FDI is considered an alternative mode of supplying foreign markets, especially in protected markets. From this view, foreign products would be a substitute. Thus, the relationship between FDI and imports is expected to be negative. This is consistent with the transaction cost theory of multinational corporations. According to Seleka 's (2007) study on the welfare impact of import controls on Botswana's horticulture, the findings showed that over time consumer losses and quota rents rose while producer gains declined. Also, the implementation of import controls declined nominal protection rates of imports of oranges, potatoes, and onions net social losses also increased, implying that import controls have not been very effective in promoting import substitution of the horticulture products.

Mogotsi and wang'ombe (2008) carried a study on determinants of import demand in Kenya by 
International Journal of Social Science and Economic Research

ISSN: 2455-8834

Volume: 05, Issue: 07 "July 2020"

disaggregating total imports into two categories: one with domestic competing substitutes and the other without, for the period 1975-2006. This study tested the differences in the responsiveness of imports with domestic competing substitutes and those without domestic competing substitutes to changes in factors like GDP and relative import prices. The empirical results showed that GDP and relative prices were import prices. The empirical results showed that GDP and relative price were the major determinants of total imports in Kenya, while exchange rates negatively influenced the demand for imports but were statistically insignificant. That meant that exchange rate policies would not effectively regulate import demand in Kenya.

Similar studies undertaken in Botswana were, for example, the study by Grynberg and Motswapong (2011), on the effect of competition and trade policy using Botswana's poultry industry. Their findings were that the poultry sector is the most successful example of import substitution in Botswana, with the country having achieved national self-sufficiency.

In summary, at a theoretical level, the import demand function in a market economy can be fully modeled by two determinants: income and relative prices. The empirical result has shown that imports are positively correlated to GDP and negatively correlated to relative prices of imports to domestic prices. The results from empirical tests consistently indicated that the volume of imports, real income, and relative import prices are cointegrated.

This study examines if the import demand function for Nepal is determined by factors such as real GDP and the real exchange rate as a proxy for relative prices. Although another related study which examines the import substitution possibility of food and live animal, mineral fuel and lubricant) and capital goods (machinery and transport equipment) which the previous study did not take into account.

\section{METHODOLOGY}

This section presents the methodology adopted in this study. The model estimated is specified, and the measurement of variables is also discussed. Also discussed are prediction with respect to explanatory and dependent variables in the model. Furthermore, this section specifies sets of hypotheses tested in the study, details on data analysis that is employed in model estimation. Finally, it provides the sources of data of the study.

\section{Model Specification}

The traditional model suggests that import demand can be modeled by two determinants, which are relative prices and real gross domestic product. The use of double logarithmic, linear import demand function is preferred because of the superior fit and easy interpretation (Houthakker and 


\section{International Journal of Social Science and Economic Research}

ISSN: $2455-8834$

Volume: 05, Issue: 07 "July 2020"

Magee 1969.) This functional form is normally used for estimating elasticities of dependent variables with respect to explanatory variables. For example, in this study, it will show the elasticity of imports with respect to income and relative prices. This paper adopts a model used by Hibbet, Thaver (2012) in their study on import demand function for Jamaica form 1996 to 2010. Hibbert, Thaver (2012) employed cointegration analysis and error- Correction modeling to investigate Jamaica's aggregate demand function with the US and UK over the period January 1996 to September 2010. The long-run aggregate import demand function for Jamaica in natural logs was identified as:

$$
\begin{aligned}
\ln \mathrm{M}_{\mathrm{t}}=\beta_{0} & +\beta_{1} \ln \mathrm{RGDP}_{\mathrm{t}}+\beta_{2} \ln \mathrm{RP}_{\mathrm{t}}+\beta_{3} \ln \mathrm{RPF}_{\mathrm{t}}+\beta_{4} \ln \mathrm{VOL}_{\mathrm{t}} \\
& +\beta_{5} \ln \mathrm{D}_{\mathrm{t}}+\varepsilon_{\mathrm{t}}
\end{aligned}
$$

Where $\mathrm{M}_{t}$ represents the real import volume, $\mathrm{RGDP}_{t}$ is the real $\mathrm{GDP}_{t}, \mathrm{RP}_{\mathrm{t}}$ is the relative price of imports, $\mathrm{RFR}_{\mathrm{t}}$ is the real foreign reserves, $\mathrm{VOL}_{\mathrm{t}}$ is the exchange rate volatility, Dt and represents the dummy variable and the error term, respectively. Their study indicates that there is a unique cointegrating relationship between the variable in the model. Relative price was found to be more elastic in the short run than in the long run (Jamaica-us trade model) and negative in the short run for Jamaica- UK trade model. They consider foreign reserve as a critical variable to be included in the model as it affects imports positively.

The model is modified in order to investigate the responsiveness of imports to various variables postulated by theory as potential determinants of imports and those that are expected to have impacts on import volume for Nepal. The adopted model for the study, in natural logs, is the period 1974- 2018.

$$
\ln \mathrm{M}_{\mathrm{t}}=\beta_{0}+\beta_{1} \ln \mathrm{M}_{\mathrm{t}-1}+\beta_{2} \ln \mathrm{RGDP}_{\mathrm{t}}+\beta_{3} \ln \mathrm{RER}_{\mathrm{t}}+\varepsilon_{\mathrm{t}}
$$

Where $M_{t}, R_{\text {GDP }}, R_{t}$, represent the Real imports, Real GDP, and the Real exchange rate, respectively, the current level of imports is expected to be influenced by the previous period's imports, and the error term is represented by $\varepsilon_{t}$. The real exchange rate (lnRER) is the bilateral exchange rate between the Nepali rupee and us dollar, with the exchange rate defined this way, a decline in the exchange rate denotes domestic currency depreciation, and this is expected to cause an increase in prices of import, hence negatively affecting the level of import. Therefore, $\beta_{3}$ is expected to be positive. Since the main aim of this study is to examine the possibility of import substitution, how responsive imports are to a change in relative prices, if the coefficient of the real exchange rate is found to be positive and statistically significant, this will imply that a real Nepali rupee depreciation results in decline in imports of food and live 
animals, Mineral fuel and lubricants and machinery and transport equipment. Thus, such a commodity would be a good candidate for import substitution, because it would be mean that the commodity responds to a change in relative prices, therefore exchange rate policy would be used to regulate imports.

For food and live animals, and Mineral fuel and lubricants imports, the coefficients are expected to be positive. If they are greater than one, which would mean the goods are price elastic, then it would mean the two goods are good candidates for import substitution. But if the coefficients are less than one, which means both commodities are price inelastic, then the two commodities would not be good candidates to import substitute.

$$
\begin{aligned}
& \ln \text { FOOD }_{\mathrm{t}}=\beta_{0}+\beta_{1} \ln \mathrm{FOOD}_{\mathrm{t}-1}+\beta_{2} \ln \mathrm{RGDP}_{\mathrm{t}}+\beta_{3} \ln \mathrm{RER}_{\mathrm{t}}+\varepsilon_{\mathrm{t}} \\
& \ln \mathrm{FUEL}_{\mathrm{t}}=\beta_{0}+\beta_{1} \ln \mathrm{FUEL}_{\mathrm{t}-1}+\beta_{2} \ln \mathrm{RGDP}_{\mathrm{t}}+\beta_{3} \ln \mathrm{RER}_{\mathrm{t}}+\varepsilon_{\mathrm{t}}
\end{aligned}
$$

Where, $\mathrm{FOOD}=$ import of food and live animal at year $\mathrm{t}, \mathrm{FUEL}=$ import of mineral fuel and lubricant at year $\mathrm{t}$.

For machinery and transport equipment imports, depreciation of Nepalese rupee is expected to result in Nepal still importing more of the machinery. This is because machinery is a capital good needed for the development of an industrial base of the country, therefore it is expected to be price inelastic. Therefore, machinery is not expected to be a good candidate for import substitution.

$$
\begin{aligned}
\ln \text { MACHINE }_{t} & =\beta_{0}+\beta_{1} \ln \text { MACHINE }_{t-1}+\beta_{2} \ln \text { RGDP }_{t} \\
& +\beta_{3} \ln \operatorname{RER}_{t}+\varepsilon_{t}
\end{aligned}
$$

where MACHINE= import of machinery and transport equipment in year $\mathrm{t}$

According to economic theory, a positive relationship is expected between domestic income and imports, which means that the income elasticity is expected to be positive, $\beta_{2}>0$. One of the variables omitted from the model by Hibbert, Thaver (2012), as presented by equation 1, is the real foreign reserves; this is because Nepal has accumulated significant reserves when measured relative to the total imports of goods and services by a country. Thus, foreign reserves have never been a constraint for Nepal imports.

\section{Data and Estimation Technique}

\section{Unit Root Test}


International Journal of Social Science and Economic Research

ISSN: $2455-8834$

Volume: 05, Issue: 07 "July 2020"

The unit root test is conducted in order to identify the characteristics of the time series variables. The Augmented Dickey-Fuller (ADF) test is used to check whether variables are stationary or non-stationary. The test is performed on variables at level and difference form. If the variables are stationary at level, they are said to be integrated of order zero: however, if they are nonstationary at levels, the null hypothesis of the presence of unit root is not rejected, and the regression analysis would give spurious results. If the variables become stationary after first differencing, they are said to be integrated of order one.

\section{Cointegration Test}

If the variable becomes stationary when first differenced, then the next step will be to see whether the variables are cointegrated, which means that there is a long-run association or relationship among variables in the model. This study uses the Johanse cointegration test. Then the error correction model(ECM) is estimated; that is, the speed of adjustment of the variables into their long-run equilibrium can thus be estimated. But if the variables are not cointegrated, the vector autoregression (VAR) model is estimated. The ECM is powerful since it allows for the estimation of both short-run and long-run effects of explanatory time series variables. Also, this model captures the speed of adjustment and incorporates the short run time factor.

\section{Data Source and Limitations}

The source of data used includes the Government of Nepal, the ministry of finance, the department of customs, the central bank of Nepal (NRB), and international financial statistics. The study uses annual data from 1974 to 2018 , and the period of study was mainly dictated by the availability of data on variables to be used in the study. The study uses secondary data; therefore, results will depend on the degree of the reliability of data used. The result will also depend on the model specification, estimation, and modifications of the methodology employed. Import demand function in the study does not take into account components such as exchange rate volatility, as it is difficult to measure.

\section{ESTIMATION AND ANALYSIS OF REGRESSION RESULT}

This section presents the regression results of the study through the data analysis process. The chapter begins by testing the unit root of collected data, followed by Johansen's cointegration, if the series are integrated of the same order. This is followed by the estimation of the Error Correction Model (ECM) if cointegration exists among the variables of the study. If not VAR model is applied.

Stationarity Tests 
The econometric theory is based on the assumption of stationary. The use of standard econometric techniques to analyze time-series requires the underlying variables to be stationary. The problems that are associated with non-stationary data are well established in the literature. Granger (1987) notes that to address these problems is to estimate a sufficiently complex dynamic specification, which includes lagged dependent and independent variables. He argued that the main aim of that approach is to make residuals stationary. The problems caused by nonstationary data can also be avoided by cointegrating the series. The Augmented Dickey- Fuller (ADF) test will be used to test for stationarity of the variables despite the fact that this test suffers (like many other unit root test) from poor size and power properties especially in small samples these variables will be tested at level form and where they are found to be non- stationary the technique of first-differencing will be applied to see if they can be stationary at first difference. The test results are presented below.

\section{Table 2: UNIT ROOT TEST}

\begin{tabular}{|c|c|c|c|c|c|c|}
\hline $\begin{array}{l}\text { UNIT ROOT TEST RESULTS TABLE (ADF) } \\
\text { Null Hypothesis: the variable has a unit root }\end{array}$ & $\begin{array}{c}\text { TABLE (AD } \\
\text { has a unit r } \\
\text { At Level }\end{array}$ & & & & & \\
\hline With Constant & $\begin{array}{c}\text { t-Statistic } \\
\text { Prob. }\end{array}$ & $\begin{array}{l}\text { FOOD } \\
0.3826 \\
\mathbf{0 . 9 7 9 9}\end{array}$ & $\begin{array}{c}\text { FUEL } \\
-0.2924 \\
\mathbf{0 . 9 1 7 6}\end{array}$ & $\begin{array}{l}\text { GDP } \\
1.2935 \\
\mathbf{0 . 9 9 8 2}\end{array}$ & $\begin{array}{c}\text { MACHINE } \\
-0.6007 \\
\mathbf{0 . 8 5 9 8}\end{array}$ & $\begin{array}{c}\text { RER } \\
-1.2993 \\
\mathbf{0 . 6 2 1 2}\end{array}$ \\
\hline With Constant \& Trend & $\begin{array}{c}\text { t-Statistic } \\
\text { Prob. }\end{array}$ & $\begin{array}{c}\mathrm{n} 0 \\
-2.4656 \\
\mathbf{0 . 3 4 2 7}\end{array}$ & $\begin{array}{c}\text { n0 } \\
-4.2511 \\
\mathbf{0 . 0 0 8 6}\end{array}$ & $\begin{array}{c}\mathrm{n} 0 \\
-1.4545 \\
\mathbf{0 . 8 2 9 7}\end{array}$ & $\begin{array}{c}\mathrm{n} 0 \\
-2.3569 \\
\mathbf{0 . 3 9 5 9}\end{array}$ & $\begin{array}{c}\text { n0 } \\
-0.8104 \\
0.9566\end{array}$ \\
\hline Without Constant \& Trend & $\begin{array}{c}\text { t-Statistic } \\
\text { Prob. } \\
\text { At First }\end{array}$ & $\begin{array}{c}\text { n0 } \\
4.5845 \\
\mathbf{1 . 0 0 0 0} \\
\text { n0 } \\
\text { ifference }\end{array}$ & $\begin{array}{l}{ }^{* * *} \\
5.2706 \\
1.0000 \\
\text { n0 }\end{array}$ & $\begin{array}{l}\text { n0 } \\
5.8715 \\
\mathbf{1 . 0 0 0 0} \\
\text { n0 }\end{array}$ & $\begin{array}{l}\text { n0 } \\
6.2778 \\
1.0000 \\
\text { n0 }\end{array}$ & $\begin{array}{c}\text { n0 } \\
3.3189 \\
0.9996 \\
\text { n0 }\end{array}$ \\
\hline With Constant & $\begin{array}{c}\text { t-Statistic } \\
\text { Prob. }\end{array}$ & $\begin{array}{c}d(F O O D) \\
-8.1633 \\
0.0000 \\
* \star *\end{array}$ & $\begin{array}{c}\mathrm{d}(\mathrm{FUEL}) \\
-5.9425 \\
\mathbf{0 . 0 0 0 0} \\
\star \star \star\end{array}$ & $\begin{array}{c}\mathrm{d}(\mathrm{GDP}) \\
-6.1182 \\
\mathbf{0 . 0 0 0 0} \\
\star \star \star\end{array}$ & $\begin{array}{c}\mathrm{d}(\mathrm{MACHIN} \\
-7.6053 \\
\mathbf{0 . 0 0 0 0} \\
* * *\end{array}$ & $\begin{array}{c}d(\text { RER }) \\
-7.0677 \\
0.0000 \\
* * *\end{array}$ \\
\hline With Constant \& Trend & $\begin{array}{c}\text { t-Statistic } \\
\text { Prob. }\end{array}$ & $\begin{array}{c}-8.2284 \\
0.0000 \\
\star \star \star\end{array}$ & $\begin{array}{c}-5.8636 \\
0.0001 \\
\star \star \star\end{array}$ & $\begin{array}{c}-6.2014 \\
\mathbf{0 . 0 0 0 0} \\
\star \star \star \star\end{array}$ & $\begin{array}{c}-7.4870 \\
0.0000 \\
\star \star \star\end{array}$ & $\begin{array}{c}-7.1979 \\
0.0000 \\
* * *\end{array}$ \\
\hline Without Constant \& Trend & $\begin{array}{c}\text { t-Statistic } \\
\text { Prob. }\end{array}$ & $\begin{array}{c}-1.7258 \\
0.0799 \\
*\end{array}$ & $\begin{array}{c}-3.8019 \\
0.0003\end{array}$ & $\begin{array}{c}-1.1365 \\
\mathbf{0 . 2 2 8 4} \\
\text { n0 }\end{array}$ & $\begin{array}{c}-2.0065 \\
\mathbf{0 . 0 4 4 1} \\
\star \star\end{array}$ & $\begin{array}{c}-1.6290 \\
\mathbf{0 . 0 9 6 7} \\
*\end{array}$ \\
\hline
\end{tabular}

Notes:

a: $\left({ }^{*}\right)$ Significant at the $10 \% ;\left({ }^{* *}\right)$ Significant at the $5 \% ;\left(^{* * *}\right)$ Significant at the $1 \%$ and (no) Not Significant b: Lag Length based on SIC

c: Probability based on MacKinnon (1996) one-sided p-values.

This Result is The Out-Put of Program Has Developed By:

Dr. Imadeddin AIMosabbeh College of Business and Economics Qassim University-KSA 
The decision rule when using the ADF technique is that, when the calculated ADF Statistic (ADF-t) is greater than the ADF critical statistic in absolute terms, then we reject the null hypothesis, which implies a unit root. The unit root test at level shows that all variables are nonstationary with intercept except for LNFUEL, which is stationary, and all variables are nonstationary at level with intercept and trend. The different order of integration of variables at times can give spurious results in regression analysis. Therefore, variables will further be tested in their differenced forms. The result from Table shows that all other variables are stationary after the first difference except LNFUEL, which was stationary at level. Therefore, variables are integrated of the same order after the first difference implying that Johansen cointegration can be carried out below.

\section{Test for Cointegration using Johansen and ADF Unit Root Test}

\section{Food And live animal Imports Cointegration Test}

Unit root test results have shown that the variables are non-stationary at levels implying that it is essential to test whether they have a long-run relationship. The Johanse cointegration test is used to produce the result in Table below. The results show that both trace statistic and Eigenvalue tests suggest the presence of no(zero) cointegrating equations among three variables. The existence of short-run relationships among variable result in the estimation of the Vector auto regression (VAR), as presented by Table below. The optimal lag length used in VAR was determined by Schwartz Information Criterion (SIC) and the Akaike Information Criterion (AIC), respectively.

\section{Table 3: Cointegration Test for Food}

\begin{tabular}{|c|c|c|c|c|}
\hline $\begin{array}{l}\text { Hypothesized } \\
\text { No. of CE(s) }\end{array}$ & Eigenvalue & $\begin{array}{c}\text { Trace } \\
\text { Statistic }\end{array}$ & $\begin{array}{c}0.05 \\
\text { Critical Value }\end{array}$ & Prob. ** \\
\hline $\begin{array}{l}\text { None } \\
\text { At most } 1 \\
\text { At most } 2\end{array}$ & $\begin{array}{l}0.320341 \\
0.072548 \\
6.02 \mathrm{E}-07\end{array}$ & $\begin{array}{l}18.92063 \\
3.087908 \\
2.47 E-05\end{array}$ & $\begin{array}{l}29.79707 \\
15.49471 \\
3.841466\end{array}$ & $\begin{array}{l}0.4987 \\
0.9628 \\
0.9983\end{array}$ \\
\hline \multicolumn{5}{|c|}{ 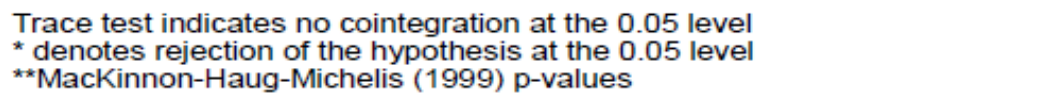 } \\
\hline $\begin{array}{l}\text { Hypothesized } \\
\text { No. of CE(s) }\end{array}$ & Eigenvalue & $\begin{array}{l}\text { Max-Eiqen } \\
\text { Statistic }\end{array}$ & $\begin{array}{c}0.05 \\
\text { Critical Value }\end{array}$ & Prob.** \\
\hline $\begin{array}{l}\text { None } \\
\text { At most } 1 \\
\text { At most } 2\end{array}$ & $\begin{array}{l}0.320341 \\
0.072548 \\
6.02 E-07\end{array}$ & $\begin{array}{l}15.83272 \\
3.087883 \\
2.47 E-05\end{array}$ & $\begin{array}{l}21.13162 \\
14.26460 \\
3.841466\end{array}$ & $\begin{array}{l}0.2348 \\
0.9407 \\
0.9983\end{array}$ \\
\hline
\end{tabular}

Max-eigenvalue test indicates no cointegration at the 0.05 level

* denotes rejection of the hypothesis at the 0.05 level

**MacKinnon-Haug-Michelis (1999) p-values 


\section{Mineral fuel and lubricant Imports Cointegration Test}

The Unit root result has shown that variables are non-stationary at level, and the Johansen cointegration test produced a result in Table 3 below. The results show that there is no cointegrating equations among FUEL, RER and RGDP variables. The optimal lag length used in VAR was determined by the Schwartz Information Criterion (SIC) and the Akaike Information Criterion(AIC), respectively. The VAR for mineral fuel and lubricant will then be estimated in Table 3

\section{Table 4: Cointegration for Fuel}

\begin{tabular}{|c|c|c|c|c|}
\hline $\begin{array}{l}\text { Hypothesized } \\
\text { No. of CE(s) }\end{array}$ & Eigenvalue & $\begin{array}{l}\text { Trace } \\
\text { Statistic }\end{array}$ & $\begin{array}{c}0.05 \\
\text { Critical Value }\end{array}$ & Prob. ** \\
\hline $\begin{array}{l}\text { None } \\
\text { At most } 1 \\
\text { At most } 2\end{array}$ & $\begin{array}{l}0.327447 \\
0.098466 \\
7.33 E-05\end{array}$ & $\begin{array}{l}20.51662 \\
4.252973 \\
0.003004\end{array}$ & $\begin{array}{l}29.79707 \\
15.49471 \\
3.841466\end{array}$ & $\begin{array}{l}0.3885 \\
0.8821 \\
0.9547\end{array}$ \\
\hline \multicolumn{5}{|c|}{$\begin{array}{l}\text { Trace test indicates no cointegration at the } 0.05 \text { level } \\
{ }^{*} \text { denotes rejection of the hypothesis at the } 0.05 \text { level } \\
{ }^{* *} \text { MacKinnon-Haug-Michelis (1999) p-values }\end{array}$} \\
\hline \multicolumn{5}{|c|}{ Unrestricted Cointegration Rank Test (Maximum Eigenvalue) } \\
\hline $\begin{array}{l}\text { Hypothesized } \\
\text { No. of CE(s) }\end{array}$ & Eigenvalue & $\begin{array}{l}\text { Max-Eigen } \\
\text { Statistic }\end{array}$ & $\begin{array}{c}0.05 \\
\text { Critical Value }\end{array}$ & Prob. ** \\
\hline $\begin{array}{l}\text { None } \\
\text { At most } 1 \\
\text { At most } 2\end{array}$ & $\begin{array}{l}0.327447 \\
0.098466 \\
7.33 E-05\end{array}$ & $\begin{array}{l}16.26365 \\
4.249969 \\
0.003004\end{array}$ & $\begin{array}{l}21.13162 \\
14.26460 \\
3.841466\end{array}$ & $\begin{array}{l}0.2098 \\
0.8321 \\
0.9547\end{array}$ \\
\hline
\end{tabular}

Max-eigenvalue test indicates no cointegration at the 0.05 level

* denotes rejection of the hypothesis at the 0.05 level

** MacKinnon-Haug-Michelis (1999) p-values

\section{Machinery and Transport Equipment Imports Cointegration test}

Unit root results have shown that the variable is stationary at first difference, and the Johansen Cointegration suggested that there is no cointegrating equations among three variables, which are MACHINERY, RER, and RGDP. The optimal lag length used in VAR was determined by Schwartz Information Criterion(SIC) and the Akaike Information Criterion (AIC), respectively. This VAR for machinery imports will then be estimated. 
International Journal of Social Science and Economic Research

ISSN: $2455-8834$

Volume: 05, Issue: 07 "July 2020"

Table 5: Cointegration test for machinery

\begin{tabular}{|c|c|c|c|c|}
\hline $\begin{array}{l}\text { Hypothesized } \\
\text { No. of CE(s) }\end{array}$ & Eigenvalue & $\begin{array}{l}\text { Trace } \\
\text { Statistic }\end{array}$ & $\begin{array}{l}0.05 \\
\text { Critical Value }\end{array}$ & Prob. ** \\
\hline $\begin{array}{c}\text { None } \\
\text { At most } 1 \\
\text { At most } 2\end{array}$ & $\begin{array}{l}0.354514 \\
0.143730 \\
0.007068\end{array}$ & $\begin{array}{l}24.60056 \\
6.652755 \\
0.290811\end{array}$ & $\begin{array}{l}29.79707 \\
15.49471 \\
3.841466\end{array}$ & $\begin{array}{l}0.1762 \\
0.6183 \\
0.5897\end{array}$ \\
\hline \multicolumn{5}{|c|}{$\begin{array}{l}\text { Trace test indicates no cointegration at the } 0.05 \text { level } \\
{ }^{*} \text { denotes rejection of the hypothesis at the } 0.05 \text { level } \\
{ }^{* *} \text { MacKinnon-Haug-Michelis (1999) p-values } \\
\text { Unrestricted Cointegration Rank Test (Maximum Eigenvalue) }\end{array}$} \\
\hline $\begin{array}{l}\text { Hypothesized } \\
\text { No. of CE(s) }\end{array}$ & Eigenvalue & $\begin{array}{l}\text { Max-Eigen } \\
\text { Statistic }\end{array}$ & $\begin{array}{c}0.05 \\
\text { Critical Value }\end{array}$ & Prob.** \\
\hline $\begin{array}{c}\text { None } \\
\text { At most } 1 \\
\text { At most } 2\end{array}$ & $\begin{array}{l}0.354514 \\
0.143730 \\
0.007068\end{array}$ & $\begin{array}{l}17.94781 \\
6.361944 \\
0.290811\end{array}$ & $\begin{array}{l}21.13162 \\
14.26460 \\
3.841466\end{array}$ & $\begin{array}{l}0.1318 \\
0.5672 \\
0.5897\end{array}$ \\
\hline
\end{tabular}

Max-eigenvalue test indicates no cointegration at the 0.05 level

* denotes rejection of the hypothesis at the 0.05 level

***MacKinnon-Haug-Michelis (1999) p-values

\section{The Vector auto regression (VAR) Results}

Since the results above show that there is only short long relationship between variables, then the Vector auto regression (VAR) is estimated for each of the three models. The regression model to be estimated are specified as follows:

$$
\begin{aligned}
\ln \text { FOOD }_{\mathrm{t}}= & \beta_{0}+\beta_{1} \mathrm{D} \ln \mathrm{FOOD}_{\mathrm{t}-1}+\beta_{2} \mathrm{D} \ln \mathrm{FOOD}_{\mathrm{t}-2}+\beta_{3} \mathrm{D} \ln \mathrm{RGDP}_{\mathrm{t}-1} \\
& +\beta_{4} \mathrm{D} \ln \mathrm{RGDP}_{\mathrm{t}-2}+\beta_{5} \mathrm{D} \ln \mathrm{RER}_{\mathrm{t}-1}+\beta_{6} \mathrm{D}_{\ln \mathrm{RER}_{\mathrm{t}-2}+\varepsilon_{\mathrm{t}}}
\end{aligned}
$$

$\ln$ FUEL $_{\mathrm{t}}=\beta_{0}+\beta_{1} \mathrm{D} \ln$ FUEL $_{\mathrm{t}-1}+\beta_{2} \mathrm{D} \ln \mathrm{FUEL}_{\mathrm{t}-2}+\beta_{3} \mathrm{D} \ln \mathrm{RGDP}_{\mathrm{t}-1}$

$$
+\beta_{4} \mathrm{D} \ln \mathrm{RGDP}_{\mathrm{t}-2}+\beta_{5} \mathrm{D} \ln \mathrm{RER}_{\mathrm{t}-1}+\beta_{6} \mathrm{D}_{\ln \mathrm{RER}_{\mathrm{t}-2}+\varepsilon_{\mathrm{t}}}
$$

$\ln$ MACHINERY

$$
\begin{aligned}
& =\beta_{0}+\beta_{1} D \ln \text { MACHINERY }_{\mathrm{t}-1}+\beta_{2} D \ln \mathrm{MACHINERY}_{\mathrm{t}-2} \\
& +\beta_{3} \mathrm{D} \ln \mathrm{RGDP}_{\mathrm{t}-1}+\beta_{4} \mathrm{D} \ln \mathrm{RGDP}_{\mathrm{t}-2}+\beta_{5} \mathrm{D}_{\mathrm{Ln}} \mathrm{RER}_{\mathrm{t}-1} \\
& +\beta_{6} \mathrm{D} \ln \mathrm{RER}_{\mathrm{t}-2}+\varepsilon_{\mathrm{t}}
\end{aligned}
$$

The result forms the models above are presented below: for FOOD ( Food and live animal), FUEL (Mineral fuel and lubricant Imports), and MACHINERY (Machinery and Transport 
Equipment Imports), respectively. These include the diagnostic tests that test for heteroscedasticity, serial correlation, and normality of residuals.

\section{VAR Result for FOOD Model Estimated by OLS}

\section{Table 6: VAR for FOOD}

\begin{tabular}{|c|c|c|c|c|}
\hline \multicolumn{5}{|c|}{$\begin{array}{l}\text { Dependent Variable: FOOD } \\
\text { Method: Least Squares (Gauss-Newton / Marquardt steps) } \\
\text { Date: } 05 / 06 / 20 \text { Time: } 19: 51 \\
\text { Sample (adjusted): } 344 \\
\text { Included observations: } 42 \text { after adjustments } \\
\text { FOOD }=C(1)^{\star} \mathrm{FOOD}(-1)+\mathrm{C}(2)^{*} \mathrm{FOOD}(-2)+\mathrm{C}(3)^{*} \mathrm{GDP}(-1)+\mathrm{C}(4)^{\star} \mathrm{GDP}(-2) \\
\quad \mathrm{C}(5)^{*} \mathrm{RER}(-1)+\mathrm{C}(6)^{*} \mathrm{RER}(-2)+\mathrm{C}(7)\end{array}$} \\
\hline & Coefficient & Std. Error & $\mathrm{t}$-Statistic & Prob. \\
\hline$C(1)$ & 0.458512 & 0.160504 & 2.856701 & 0.0072 \\
\hline$C(2)$ & 0.109404 & 0.153801 & 0.711332 & 0.4816 \\
\hline$C(3)$ & -0.058252 & 0.432154 & -0.134794 & 0.8935 \\
\hline $\mathrm{C}(4)$ & 0.862339 & 0.478459 & 1.802326 & 0.0801 \\
\hline$C(5)$ & 0.231832 & 0.358927 & 0.645904 & 0.5226 \\
\hline$C(6)$ & -0.033015 & 0.358842 & -0.092004 & 0.9272 \\
\hline$C(7)$ & 1.756309 & 0.498006 & 3.526681 & 0.0012 \\
\hline R-squared & 0.990686 & \multicolumn{2}{|c|}{ Mean dependent var } & 8.554265 \\
\hline Adjusted R-squared & 0.989089 & \multicolumn{2}{|c|}{ S.D. dependent var } & 1.803172 \\
\hline S.E. of regression & 0.188351 & \multicolumn{2}{|c|}{ Akaike info criterion } & -0.350003 \\
\hline Sum squared resid & 1.241669 & \multicolumn{2}{|c|}{ Schwarz criterion } & -0.060391 \\
\hline Log likelihood & 14.35006 & \multirow{2}{*}{\multicolumn{2}{|c|}{$\begin{array}{l}\text { Hannan-Quinn criter. } \\
\text { Durbin-Watson stat }\end{array}$}} & -0.243849 \\
\hline F-statistic & 620.4477 & & & 1.983302 \\
\hline Prob(F-statistic) & 0.000000 & & & \\
\hline
\end{tabular}

Information Criteria. EViews 10 chose lags (, 2) for FOOD, GDP, RER respectively with the specified information. Results of VAR model estimation results are reported in table $5 \mathrm{R}$ squared value is found to be 0.99 which indicates that 99 percent variations in the dependent variable have been explained by the independent variables. The model is a good fit. The value of DW statistics is 1.98 which indicate that there is no auto correlation among the variables. In this model, GDP and previous FOOD imports appears to be the most significant variables in determining food imports. The GDP coefficient is negative at lag 1 but it's positive at lag 2 and statistically significant at $10 \%$. This positive sign indicates that a $1 \%$ increase in GDP will lead to increase in Nepal demand for FOOD by $0.86 \%$. Also, previous food imports coefficient is statistically significant at $1 \%$ with a positive sign, implying that a unit percentage change in previous food imports leads to $0.45 \%$ increase in current food imports. The real exchange rate coefficient is 0.23 and it has positive sign which correspond to our expectation. But this 
coefficient is statistically insignificant at $10 \%$. At lag 2 exchange rate have negative coefficient 0.03 which imply a unit percentage change in exchange rate leads to 0.03 percentage decrease in import of food.

\section{Residual diagnostics}

\section{LM Test}

\section{Table 7: LM Test FOOD}

\begin{tabular}{|llll|}
\hline \multicolumn{4}{|l|}{ Breusch-Godfrey Serial Correlation LM Test: } \\
\hline \hline F-statistic & 0.565162 & Prob. F(2,33) & 0.5737 \\
Obs*R-squared & 1.390951 & Prob. Chi-Square(2) & 0.4988 \\
\hline \hline
\end{tabular}

After the estimation of VAR model, we ran the Breusch-Godfrey LM test on the residuals to check if our model suffered from the problem of serial correlation. The F-statistics and the respective probability values clearly indicate that there is no issue of serial correlation. As the probability value associated with the F-statistics is 0.57 , clearly above the critical value of $5 \%$, we accept the null hypothesis of no serial correlation.

\section{Normality Test}

\section{Table 8: Normality Test for FOOD Model}
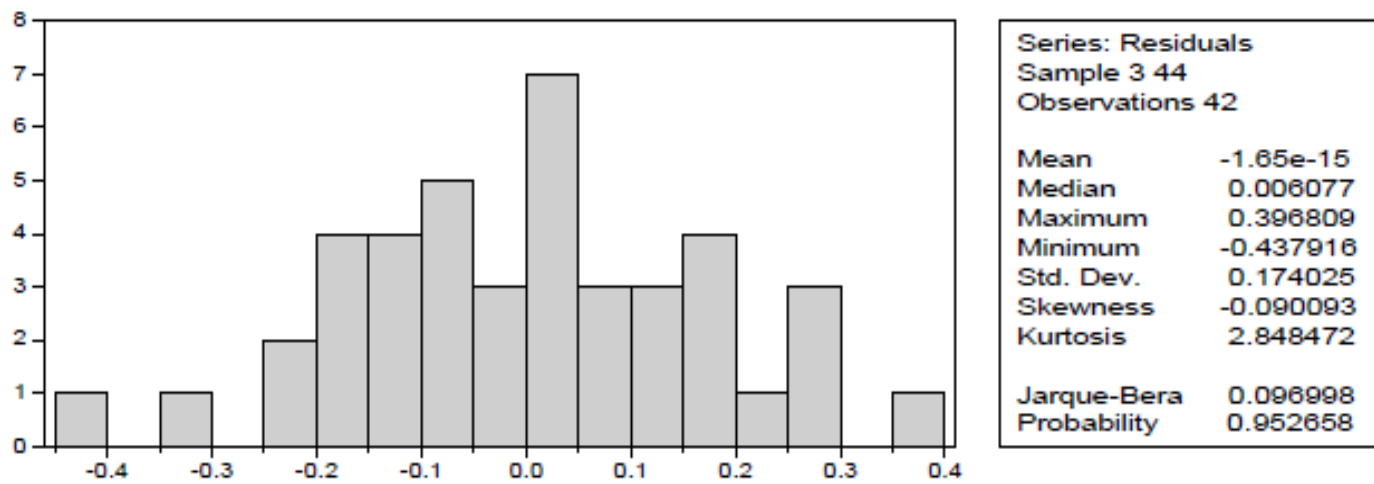

we have a normally distributed residual from the VAR estimation. This can be confirmed by the Jarque-Bera probability of 0.95 which clearly is more that the critical $5 \%$ mark and thus fails to reject the null hypothesis of Normal distribution of the residuals. Additionally, this test also shows us the skewness and kurtosis of the residuals. Rule of thumb on skewness tells us that a 
International Journal of Social Science and Economic Research

ISSN: $2455-8834$

Volume: 05, Issue: 07 "July 2020"

skewness of -0.09 which lies between 0.5 and -0.5 means that the distribution of the residuals is approximately symmetrical. Kurtosis value of 2.84 which is less than 3 means that the distribution of residuals are mesokurtic and there are not many data in the tails.

\section{Breusch-Pagan Test for Heteroscedasticity}

Table 9: Heteroscedasticity Test for FOOD Model

\begin{tabular}{|c|c|c|c|}
\hline \multicolumn{4}{|c|}{ Heteroskedasticity Test: Breusch-Pagan-Godfrey } \\
\hline F-statistic & 2.094943 & Prob. F(6,35) & 0.0788 \\
\hline Obs*R-squared & 11.09795 & Prob. Chi-Square(6) & 0.0854 \\
\hline Scaled explained SS & 7.123001 & Prob. Chi-Square(6) & 0.3096 \\
\hline
\end{tabular}

we ran the Breusch-Pagan-Godfrey test to ascertain whether our model suffers from heteroscedasticity. As observed from the table we see the probability values associated with Fstatistics and $\mathrm{R}$ squared are both higher than the 5\% value letting us accept the null hypothesis no heteroscedasticity and confirm that the model is homoskedastic which is desirable.

\section{VAR Result for FUEL MODEL Estimated by OLS}

\section{Table 10: VAR for FUEL}

\begin{tabular}{|c|c|c|c|c|}
\hline \multicolumn{5}{|c|}{$\begin{array}{l}\text { Dependent Variable: FUEL } \\
\text { Method: Least Squares (Gauss-Newton / Marquardt steps) } \\
\text { Date: } 05 / 06 / 20 \text { Time: } 20: 20 \\
\text { Sample (adjusted): } 344 \\
\text { Included observations: } 42 \text { after adjustments } \\
\text { FUEL }=\mathrm{C}(1)^{*} \mathrm{FUEL}(-1)+\mathrm{C}(2)^{*} \mathrm{FUEL}(-2)+\mathrm{C}(3)^{*} \mathrm{GDP}(-1)+\mathrm{C}(4)^{*} \mathrm{GDP}(-2)+ \\
\quad \mathrm{C}(5)^{*} \mathrm{RER}(-1)+\mathrm{C}(6)^{*} \mathrm{RER}(-2)+\mathrm{C}(7)\end{array}$} \\
\hline & Coefficient & Std. Error & t-Statistic & Prob. \\
\hline $\begin{array}{l}C(1) \\
C(2) \\
C(3) \\
C(4) \\
C(5) \\
C(6) \\
C(7)\end{array}$ & $\begin{array}{r}0.788237 \\
-0.244548 \\
0.712707 \\
0.003357 \\
0.089123 \\
0.391325 \\
1.119950\end{array}$ & $\begin{array}{l}0.164894 \\
0.158476 \\
0.420236 \\
0.428535 \\
0.336614 \\
0.367862 \\
0.366930\end{array}$ & $\begin{array}{r}4.780277 \\
-1.543127 \\
1.695969 \\
0.007834 \\
0.264762 \\
1.063782 \\
3.052214\end{array}$ & $\begin{array}{l}0.0000 \\
0.1318 \\
0.0988 \\
0.9938 \\
0.7927 \\
0.2947 \\
0.0043\end{array}$ \\
\hline $\begin{array}{l}\text { R-squared } \\
\text { Adjusted R-squared } \\
\text { S.E. of regression } \\
\text { Sum squared resid } \\
\text { Log likelihood } \\
\text { F-statistic } \\
\text { Prob(F-statistic) }\end{array}$ & $\begin{array}{l}0.993754 \\
0.992683 \\
0.177029 \\
1.096878 \\
16.95381 \\
928.0836 \\
0.000000\end{array}$ & \multicolumn{2}{|c|}{$\begin{array}{l}\text { Mean dependent var } \\
\text { S.D. dependent var } \\
\text { Akaike info criterion } \\
\text { Schwarz criterion } \\
\text { Hannan-Quinn criter. } \\
\text { Durbin-Watson stat }\end{array}$} & $\begin{array}{r}8.866983 \\
2.069584 \\
-0.473991 \\
-0.184379 \\
-0.367837 \\
2.063170\end{array}$ \\
\hline
\end{tabular}


Information Criteria. EViews 10 chose $\operatorname{lags}($, 2) for FUEL, GDP, RER respectively with the specified information. Results of VAR model estimation results are reported in table 9. R squared value is found to be 0.99 which indicates that 99 percent variations in the dependent variable have been explained by the independent variables. The model is a good fit. The value of DW statistics is 2.06 which indicate that there is no auto correlation among the variables. In this model, GDP and previous FUEL imports appears to be the most significant variables in determining fuel imports. The GDP coefficient is positive and statistically significant at $10 \%$. This positive sign indicates that a $1 \%$ increase in GDP will lead to increase in Nepal demand for FUEL by $0.71 \%$. Also, previous food imports coefficient is statistically significant at $1 \%$ with a positive sign, implying that a unit percentage change in previous food imports leads to $0.78 \%$ increase in current food imports. The real exchange rate coefficient is 0.08 and it has positive sign which correspond to our expectation. But this coefficient is statistically insignificant at $10 \%$.

\section{Residual diagnostics LM Test}

Table 11: LM Test for FUEL Model

\begin{tabular}{|llll|}
\hline \multicolumn{4}{|l|}{ Breusch-Godfrey Serial Correlation LM Test: } \\
\hline \hline F-statistic & 1.875592 & Prob. F(2,33) & 0.1692 \\
Obs* R-squared & 4.286930 & Prob. Chi-Square(2) & 0.1172 \\
\hline
\end{tabular}

After the estimation of VAR model, we ran the Breusch-Godfrey LM test on the residuals to check if our model suffered from the problem of serial correlation. The F-statistics and the respective probability values clearly indicate that there is no issue of serial correlation. As the probability value associated with the F-statistics is 0.16 , clearly above the critical value of $5 \%$, we accept the null hypothesis of no serial correlation.

\section{Normality Test}

Table 12: Normality Test for FUEL Model
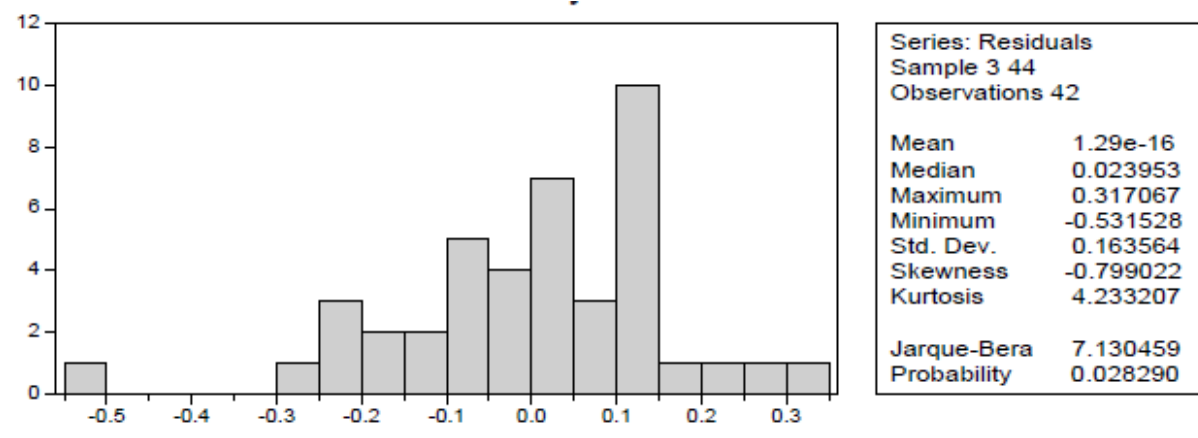
The normality test indicates that residuals from this model are not normally distributed. This can be confirmed by the Jarque-Bera probability of 0.02 which clearly is less than the critical $5 \%$ mark and thus do not reject null hypothesis of normal distribution of the residuals. This is because given few observations; the residuals may not attain normal distribution within the sample period, (Gujarati, 2003).

\section{Breusch-Pagan test for heteroscedasticity}

\section{Table 13: Heteroscedasticity Test for FUEL Model}

\begin{tabular}{|lrll|}
\hline \multicolumn{4}{|l|}{ Heteroskedasticity Test: Breusch-Pagan-Godfrey } \\
\hline F-statistic & 1.537348 & Prob. F(6,35) & 0.1950 \\
ObsR-squared & 8.760198 & Prob. Chi-Square(6) & 0.1875 \\
Scaled explained SS & 9.834561 & Prob. Chi-Square(6) & 0.1318 \\
\hline
\end{tabular}

we ran the Breusch-Pagan-Godfrey test to ascertain whether our model suffers from heteroscedasticity. As observed from the table we see the probability values associated with Fstatistics and $\mathrm{R}$ squared are both higher than the 5\% value letting us accept the null hypothesis no heteroscedasticity and confirm that the model is homoskedastic which is desirable.

\section{VAR Result for MACHINERY MODEL Estimated by OLS}

Table 14: VAR for MACHINERY

\begin{tabular}{|c|c|c|c|c|}
\hline \multicolumn{5}{|c|}{$\begin{array}{l}\text { Dependent Variable: MACHINERY } \\
\text { Method: Least Squares (Gauss-Newton / Marquardt steps) } \\
\text { Date: 05/06/20 Time: } 20: 25 \\
\text { Sample (adjusted): } 344 \\
\text { Included observations: } 42 \text { after adjustments } \\
\text { MACHINERY }=\mathrm{C}(1)^{\star} \mathrm{MACHINERY}(-1)+\mathrm{C}(2)^{\star} \mathrm{MACHINERY}(-2)+\mathrm{C}(3)^{\star} \mathrm{GD} \\
\quad-1)+\mathrm{C}(4)^{\star} \mathrm{GDP}(-2)+\mathrm{C}(5)^{\star} \mathrm{RER}(-1)+\mathrm{C}(6)^{\star} \mathrm{RER}(-2)+\mathrm{C}(7)\end{array}$} \\
\hline & Coefficient & Std. Error & t-Statistic & Prob. \\
\hline$C(1)$ & 0.807055 & 0.198048 & 4.075041 & 0.0003 \\
\hline $\mathrm{C}(2)$ & 0.077346 & 0.191116 & 0.404706 & 0.6882 \\
\hline $\mathrm{C}(3)$ & -0.017328 & 0.430507 & -0.040250 & 0.9681 \\
\hline $\mathrm{C}(4)$ & 0.245953 & 0.397884 & 0.618151 & 0.5405 \\
\hline $\mathrm{C}(5)$ & -0.251543 & 0.350915 & -0.716820 & 0.4782 \\
\hline $\mathrm{C}(6)$ & 0.287239 & 0.318681 & 0.901335 & 0.3736 \\
\hline$C(7)$ & 0.750582 & 0.482247 & 1.556425 & 0.1286 \\
\hline & 0.993833 & Mean depe & ent var & 9.382144 \\
\hline Adjusted R-squared & 0.992775 & S.D. depen & ht var & 1.859795 \\
\hline S.E. of regression & 0.158080 & Akaike info & terion & -0.700419 \\
\hline
\end{tabular}


International Journal of Social Science and Economic Research

ISSN: 2455-8834

Volume: 05, Issue: 07 "July 2020"

\begin{tabular}{|lllr|} 
Sum squared resid & 0.874626 & Schwarz criterion & -0.410807 \\
Log likelihood & 21.70879 & Hannan-Quinn criter. & -0.594264 \\
F-statistic & 939.9871 & Durbin-Watson stat & 1.847933 \\
Prob(F-statistic) & 0.000000 & & \\
\hline
\end{tabular}

Criteria. EViews 10 chose lags (2) for MACHINERY, GDP, RER respectively with the specified information. Results of VAR model estimation results are reported in table 9 . $\mathrm{R}$ squared value is found to be 0.99 which indicates that 99 percent variations in the dependent variable have been explained by the independent variables. The model is a good fit. The value of DW statistics is 1.84 which indicate that there is no auto correlation among the variables. In this model and previous machinery imports appears to be the most significant variables in determining machinery imports. The GDP coefficient is negative and statistically insignificant at $10 \%$. Also, previous machinery imports coefficient is statistically significant at $1 \%$ with a positive sign, implying that a unit percentage change in previous food imports leads to $0.80 \%$ increase in current Machinery imports. The real exchange rate coefficient is -0.25 and it has negative sign. But this coefficient is statistically insignificant at $10 \%$.

\section{Residual diagnostics LM Test}

Table 15: LM Test for MACHINERY Model

\begin{tabular}{|llll|}
\hline \multicolumn{4}{|l|}{ Breusch-Godfrey Serial Correlation LM Test: } \\
\hline \hline F-statistic & 1.071187 & Prob. F(2,33) & 0.3542 \\
Obs*R-squared & 2.560434 & Prob. Chi-Square(2) & 0.2780 \\
\hline
\end{tabular}

After the estimation of VAR model, we ran the Breusch-Godfrey LM test on the residuals to check if our model suffered from the problem of serial correlation. The F-statistics and the respective probability values clearly indicate that there is no issue of serial correlation. As the probability value associated with the F-statistics is 0.35 , clearly above the critical value of $5 \%$, we accept the null hypothesis of no serial correlation.

\section{Normality Test}


International Journal of Social Science and Economic Research

ISSN: 2455-8834

Volume: 05, Issue: 07 "July 2020"

Table 16: Normality Test for MACHINERY Model

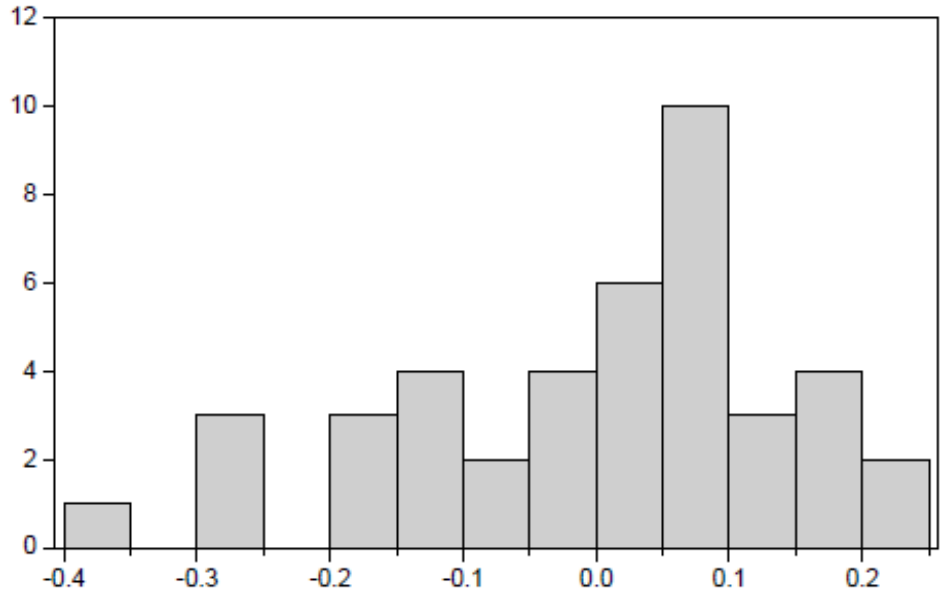

\begin{tabular}{|lr|}
\hline \multicolumn{2}{|l|}{ Series: Residuals } \\
Sample 3 44 \\
\multicolumn{2}{|l|}{ Observations 42} \\
Mean & $-1.46 \mathrm{e}-16$ \\
Median & 0.019367 \\
Maximum & 0.249943 \\
Minimum & -0.363103 \\
Std. Dev. & 0.146056 \\
Skewness & -0.514062 \\
Kurtosis & 2.745413 \\
& \\
Jarque-Bera & 1.963247 \\
Probability & 0.374702 \\
\hline
\end{tabular}

As above we have a normally distributed residual from the VAR estimation. This can be confirmed by the Jarque-Bera probability of 0.37 which clearly is more that the critical $5 \%$ mark and thus fails to reject the null hypothesis of Normal distribution of the residuals. Additionally, this test also shows us the skewness and kurtosis of the residuals. Rule of thumb on skewness tells us that a skewness of -0.5 which lies between 0.5 and -0.5 means that the distribution of the residuals is approximately symmetrical. Kurtosis value of 2.74 which is less than 3 means that the distribution of residuals are mesokurtic and there are not many data in the tails.

\section{Breusch-Pagan test for heteroscedasticity}

Table 17: Heteroscedasticity Test for MACHINERY Model

\begin{tabular}{|llll|}
\hline Heteroskedasticity Test: Breusch-Pagan-Godfrey & \\
\hline F-statistic & 0.407769 & Prob. F(6,35) & 0.8688 \\
Obs ${ }^{*}$ R-squared & 2.744112 & Prob. Chi-Square(6) & 0.8402 \\
Scaled explained SS & 1.663058 & Prob. Chi-Square(6) & 0.9479 \\
\hline
\end{tabular}

we ran the Breusch-Pagan-Godfrey test to ascertain whether our model suffers from heteroscedasticity. As observed from the above table we see the probability values associated with F-statistics and $\mathrm{R}$ squared are both higher than the 5\% value letting us accept the null hypothesis no heteroscedasticity and confirm that the model is homoskedastic which is desirable.

\section{CONCLUSION AND POLICY RECOMMENDATIONS}

The main aim of this study is to estimate the import demand function for disaggregated FOOD (food and live animals), FUEL (Mineral fuel and lubricants) and MACHINERY (machinery and 


\section{International Journal of Social Science and Economic Research}

ISSN: $2455-8834$

Volume: 05, Issue: 07 "July 2020"

transport equipment) form 1974-2018, and see the possibility of import substitution of these commodities.

\section{Summary of the results and conclusions}

Most of the results of this study are consistent with findings from previous studies, while others are not. For example, this study found that the real exchange rate is statistically insignificant for all three categories of imports: FOOD (food and live animal), FUEL (Mineral fuel and lubricants) and MACHINERY (machinery, and transport equipment). A similar result was found by Mogotsi and wang (2008) for Kenya and Motlaleng and Modisaatsone (2013) for Botswana. Who found that import of commodities has a statistically insignificant relationship with the real exchange rate. This implies that the RER, which is considered here as the best instrument that can be used to influence the domestic price of importable, has no influence in determining the possibility of import substitution on all categories of commodities studied: FOOD (food and live animal), FUEL (Mineral fuel and lubricants) and MACHINERY (machinery, and transport equipment).

The statistically insignificant results of the exchange rate at $10 \%$ in determining these categories of imports could mean that these imported commodities are superior to domestic import substitutes, such that even if there is depreciation of the currency, which causes a rise in the price of the imported goods, Nepal consumers and producers (in the case of machinery) still demand these imports. This means that exchange rate depreciation or devaluation, in an attempt to reduce these imports to stimulate local production, would be ineffective in regulating imports of such goods into the country. Perhaps an explanation for this low-price elasticity of the imports is that they are necessary goods. Especially for food and machinery; thus, they are not impacted must by any relative price changes, thus making them price inelastic. For food (which includes food and live animal), the possible explanation is that local consumers have a high preference for variety, thus making them be inelastic to import prices. This shows that the real exchange rate is not the right policy tool to use to pursue the promotion of import substitution of these commodities.

Another variable in the import function estimated, GDP is found to be statistically significant for Food and fuel but not for machinery. Where the GDP is statistically significant, this is consistent with theory because growth in economic activity (GDP) is expected to cause a country to import more. This is verified by several studies, including Mogotis and wang(2008), Motlaleng and Modisaatsone(2013), and Hibbert, Thaver(2012). However, this is not always the case because the increase in GDP could mean increased local output and increase efficiency in production, which might shift the demand for local products. Hence in this study, it seems like GDP has no effect on demand for food imports. Therefore, we can conclude that food may be importsubstitutable because, as income rises, imports do not seem to rise significantly, which may 
International Journal of Social Science and Economic Research

ISSN: $2455-8834$

Volume: 05, Issue: 07 "July 2020"

mean that the increase in demand for the food from the rise in domestic income can be met with local production.

\section{Policy recommendations}

Since the real exchange rate is seen here to be ineffective in determining the demand for imports of food, fuel and machinery, in Nepal, implying that a real depreciation or appreciation of exchange rate will have no effect on imports, this means imports of these commodities would not decline with a real depreciation or devaluation. This means that exchange rate policies might not be that important in the regulation of imports into the country. Therefore, in general, Nepal's economy can benefit by improving its export competitiveness through avoiding an overvalued exchange rate; for example, currency devaluation would promote exports without reducing importation of goods such as machinery and equipment which are necessary for the production of import substitutes and for production of the exportable commodities.

Therefore, in order for the government of Nepal, to achieve its mandate goal which is to import substitute, government has to come up with policies that revolve around providing incentive to Nepal to venture into export-oriented, large scale manufacturing and a currency devaluation would not affect imports of Mineral fuel and lubricants and machinery, therefore, providing more capital to industries which can be able to produce more of competing import substitutes.

\section{REFERENCES}

Bruton (1998), "A Reconsideration of Import substitution.”, Journal of economic literature, Volume 36(2), page 607-613.

Dutta and Ahmed (2004), "An Aggregate Import Demand Function for India: A Contegration Analysis.” “Applied Economic Letters" Volume 11(10), page 1041-1105.

Douglas A.Irwin (2002), "Interpreting the Tariff-Growth Correlation of the Late 19th Century", Aea Papers and Proceedings, Volume 92(2) page 165-169

Goldstein and M.S Khan (1985), "Income and Price effects in Foreign Trade.", Handbook of International Economic, Volume 2, page 1041-11-5.

Hibbert (2012), “An Econometric Analysis of Jamaica's Import Demand Function with the US and UK.", The International Journal of Business and Finance Research, Volume 6(1), page 109-120. 
International Journal of Social Science and Economic Research

ISSN: $2455-8834$

Volume: 05, Issue: 07 "July 2020"

Houthakker and Magee (1969), "Maximum Likelihood Estimation and Inference on Cointegration - with Application to the Demand for Money.", Oxford Bulletin of Economics and Statistics, Volume 52(2), page 169-210.

Kuzmin, (2015), "Food Security Modelling.", Biosciences Biotechnology Research Asia, volume 12(2), page 773-781

Magee (1975), "Price, Incomes, and Foreign Trade.", International Trade and Finance Frontiers for Research, page 175-252.

Matsubayashi and Hamori (2009), "Empirical Analysis of Import Demand Behavior of Least Developed Countries.”, Economic Bulletin, Volume 29(2), page 1443-1458.

Melo and vogt (1984), "Determinants of the Demand for Import of Venezuela.", Journal of Development Economic, Volume 14(3), page 351- 358.

Modisaatsone and Motlaleng (2013), "Impact of Exchange Rate Volatility on Botswanas Imports.", Journal of Business Management and Economics.", Volume 4(5), page 125138 Mogotsi and Wang (2008), "Manufactured Imports and Industrial Development the Case of Kenya", Journal of Social and Economic Policy, Volume No.2 (5), page 157-176.

Onwuka and Zoral (2009), "Foreign Direct Investment and Import Growth in Turkey.", Journal of Yasar University, volume 4(15), page 2357-2380.

Pattichis (1999), "Price and Income Elasticities of Disaggregated Imports Growth in Turkey.", Journal of Applied Economic, Volume 31(9), page 1061-1071.

Pesaran (2001), "Bounds Testing Approaches to the Analysis of Level Relationship.", Journal of Applied Econometric, Volume 16(3), page 289-326.

Rejal(2000), "Determinants of Nepalese Imports.", Journal of Asian Economics, Volume 11(3), page 347-354.

Sekwati (2010), "Botswana: A Note on Economic Diversification.", Botswana journal of Economics, Volume 7(11), Page 79-85.

Seleka (2007), "Welfare Impacts of Import Controls on Botswana's Horticulture.", Agricultural Economic, Volume 36(3), page 305-311 
International Journal of Social Science and Economic Research

ISSN: 2455-8834

Volume: 05, Issue: 07 "July 2020"

Tang (2003), “An Empirical Analysis of China's Aggregate Import Demand Function.” China Economic Review, Volume 14(2), page 142-163

Zhou and Dube (2011), "Import Demand Function: Evidence from Cibs."Journal of Economic Development, Volume 36(4), page 73-96 